\title{
Constructed Wetlands for the Pre-Treatment of Drinking Water Obtained from Coal Mines
}

\author{
Curtis J. Varnell ${ }^{*, 1}$, Salem Thawaba ${ }^{2}$ and J. Van Brahana ${ }^{3}$
}

702 Jessie Drive, Lavaca, AR 92943, USA

Ozark Hall, University of Arkansas, Fayetteville, AR, USA

P.O. Box 14, Birzeit University, West Bank, Palestine

\begin{abstract}
Greenwood, Arkansas, a city of about 7,700 people in west-central Arkansas, has experienced tremendous growth in population during the past decade. The city has the current capacity to produce $4.55 \times 10^{6} \mathrm{~L}$ of water daily. Demand for city water use is expected to exceed $6.82 \times 10^{6} \mathrm{~L}$ within the next five years. An additional $2.27 \times 10^{6} \mathrm{~L}$ per day is needed to augment the current supply.

Two abandoned, flooded coal mines located near the city have estimated water storage in excess of $1.97 \mathrm{x} 10^{9} \mathrm{~L}$ of water. The water has high concentrations of total dissolved solids (TDS), sulfate, and iron. If a decision is made to use the water, it will require treatment to reduce these constituents to acceptable levels.

Designing and constructing a viable wetland for pretreatment of mine water would offer Greenwood an inexpensive, passive method to utilize the water from the coal mines. If the city can use water from the coal mines to augment the present reservoir, the expected savings would exceed twenty million dollars. Integrating this system into the current city park system and green-space will provide a multi-purpose facility that can be used for recreation, education, and wildlife enhancement.
\end{abstract}

Terms: Phytoremediation, RAPS System, Iron hydroxide, Anoxic limestone drain, Acid mine drainage.

\section{INTRODUCTION}

Wetlands have proven to be an effective and cost efficient method to reduce unwanted constituents in wastewater [1], storm water [2], and mine water [3]. Within a wetland, several chemical and biological processes combine to remove metals and contaminants from the water. Removal mechanisms include cation exchange, chelation with wetland soils, binding with humic materials, precipitation as insoluble salts of sulfides, carbonates, and hydroxides, as well as uptake by plants algae, and bacteria [4]. Traditionally, mine waters have required the inclusion of anoxic limestone drains (ALD) as well as a reducing and alkalinity system (RAP) to insure maximum reduction of iron and sulfur and to reduce the acidity of water [5-7]. After wetland treatment, this water is than released safely into the watershed area.

Greenwood is a city of about 7,700 people located just south of Ft. Smith, Arkansas. The community serves as a residential and small business area for the southern portion of Sebastian County, Arkansas. Recently, the region has experienced a significant population influx which has negatively impacted the ability of the city to meet local water needs. An additional $2.27 \times 10^{6} \mathrm{~L}$ of water are needed to augment the current water supply.

*Address correspondence to this author at the 702 Jessie Drive, Lavaca, AR. 92943, USA; Tel: 479- 965-2191; Fax: 479-965-2723;

E-mail: cvarnell@waesc2.wsc.k12.ar.us
Two coal mines, the Fidelity and Greenwood, are abandoned, submerged, underground coal mines that are found east of the city. Cities in West Virginia [8,9]; Kentucky [10], and Oklahoma [11] successfully obtain water from coal mines for public consumption. Utilization of the water from the coal mines to augment the water within the local reservoir would provide an adequate supply of water at an affordable cost to the city for the foreseeable future.

Prior studies by the city of Greenwood and the University of Arkansas [12] have indicated that the mines contain in excess of $1.97 \times 10^{9} \mathrm{~L}$ of water. The water quality and quantity have been monitored at four test wells and eight surface sites from September 2001 to the present.

An analysis of the water (Table 1) indicates that the constituent content is comparable to that commonly found in areas of mine drainage. The conductivity readings were elevated, indicating a high total dissolved solid (TDS) content. Further analyses indicate that the high TDS is caused by large concentrations of sulfate, iron, and chloride.

The $\mathrm{pH}$ of the water within the mines is circumneutral, due in large part to alkalinity levels of $508 \mathrm{mg} / \mathrm{L}$ as calcium carbonate $\left(\mathrm{CaCO}_{3}\right)$. Water quality is variable within the coal mines, as indicated by the standard deviation of the constituents found at wells \#4, \#5, \# 6, and \#7 (standard deviation of sulfate $>238$, iron $>9.5$, chloride $>34.7$ ).

Mine chemistry is expected to change when water is extracted and reoxygenated water is introduced [13] (Robb, 
Table 1. Comparison of Water Constituents in Greenwood Mines, Greenwood Reservoir, EPA, and European Community (E.C.) Standards. [Coal Mine Constituents are the Mean of the Samples Collected During 2002, EPA Standards are for Treated Water, all Other Figures are Raw Water Samples, * Indicates Secondary EPA Water Regulations]

\begin{tabular}{|c|c|c|c|c|}
\hline & Reservoir & Coal Mine & E.P.A. (treated) & European (E.C.) Raw \\
\hline T.D.S. & $204 \mathrm{mg} / \mathrm{L}$ & $2143 \mathrm{mg} / \mathrm{L}$ & $500 \mathrm{mg} / \mathrm{L}^{*}$ & $1000 \mathrm{mg} / \mathrm{L}$ \\
\hline Nitrate & $0.09 \mathrm{mg} / \mathrm{L}$ & $0.02 \mathrm{mg} / \mathrm{L}$ & $10 \mathrm{mg} / \mathrm{L}$ & $50 \mathrm{mg} / \mathrm{L}$ \\
\hline Iron & & $20.4 \mathrm{mg} / \mathrm{L}$ & $0.3 \mathrm{mg} / \mathrm{L}^{*}$ & $2 \mathrm{mg} / \mathrm{L}$ \\
\hline Mercury & $<0$ & $<0.0005 \mathrm{mg} / \mathrm{L}$ & $0.002 \mathrm{mg} / \mathrm{L}$ & $0.001 \mathrm{mg} / \mathrm{L}$ \\
\hline Lead & $<0.001 \mathrm{mg} / \mathrm{L}$ & $0.04 \mathrm{mg} / \mathrm{L}$ & $0.015 \mathrm{mg} / \mathrm{L}$ & \\
\hline Chloride & $8.94 \mathrm{mg} / \mathrm{L}$ & $65.27 \mathrm{mg} / \mathrm{L}$ & $250 \mathrm{mg} / \mathrm{L}^{*}$ & $200 \mathrm{mg} / \mathrm{L}$ \\
\hline Bicarbonate & $33 \mathrm{mg} / \mathrm{L}$ & $362 \mathrm{mg} / \mathrm{L}$ & & \\
\hline Copper & $<0.01 \mathrm{mg} / \mathrm{L}$ & $0.01 \mathrm{mg} / \mathrm{L}$ & $1.3 \mathrm{mg} / \mathrm{L}$ & $0.05 \mathrm{mg} / \mathrm{L}$ \\
\hline pH & 7.32 & 6.4 & $6.5-8.5 *$ & $5.5-9$ \\
\hline Temp. & & $17{ }^{\circ} \mathrm{C}$ & & $25^{\circ} \mathrm{C}$ \\
\hline
\end{tabular}

1994). A lower $\mathrm{pH}$ could increase the concentration of contaminants in the water. Comparisons of mine water quality to the European Community (E.C.) raw water standards, to the EPA [4] treated maximum contaminant levels (MCL), and to current reservoir content indicate that the water from the mines would require pretreatment before use for human consumption (Table 1).

The original treatment plan was to construct a water storage and treatment facility at the site where the water was extracted. The facility would consist of a $3.78 \times 10^{6} \mathrm{~L}$ tank and the necessary equipment to pre-treat the water to lower concentrations of dissolved iron and dissolved solids. The water would then be pumped $1,829 \mathrm{~m}$ to the existing water treatment facility for additional treatment. Initial cost estimate for this facility was $\$ 1,350,000$ plus the additional cost of water treatment at the plant [14].

Opposition to this proposal came from local landowners who objected to having a pre-treatment facility constructed in a residential neighborhood. Other considerations including cost of sludge removal, treatment cost, residential property cost, and increased residential traffic contributed to a decision to look at other alternatives.

Constructed wetlands offer an inexpensive, natural, low maintenance, and long-term solution to treating water from coal mines without chemical additives. There are several very successful sites where constructed wetlands have significantly reduced sulfate, manganese, iron, and other contaminant levels similar to those found in the Greenwood mines. Since 1985, the Tennessee Valley Authority (TVA) has constructed 14 wetlands for treating acid drainage at coal mining facilities and at coal-fired power plants. Nine of these wetlands produce effluents meeting all of the National Pollu- tion Discharge Elimination System (NPDES) monitoring requirements $(\mathrm{pH}=6$ to $9 ; \mathrm{Fe}<3.0 \mathrm{mg} / \mathrm{L} ; \mathrm{Mn}<2.0 \mathrm{mg} / \mathrm{L}$; TSS $<35.0 \mathrm{mg} / \mathrm{L}$ ) with no chemical treatment [5] (Brodie, 1991). Four of the wetlands have been released from NPDES monitoring requirements. Influent water in some of the wetlands had concentrations $>170 \mathrm{mg} / \mathrm{L}$ dissolved iron, $17 \mathrm{mg} / \mathrm{L}$ dissolved manganese and $\mathrm{pH}$ as low as 3.0. Non-compliant wetlands at the TVA project have since been altered to include limestone drains to decrease $\mathrm{pH}$ and increase wetland efficiency.

Constructed wetlands in Oklahoma [15]. Appalachia and Minnesota [7], and Europe [2], have demonstrated the successful use of wetlands to treat mine water. Water from the sites above is released into the local watershed after treatment.

An additional list of successful constructed wetlands used to treat mine water is provided (Table 2). It was determined that a unique approach using a combination of a RAP and ALD system, a traditional wetland, and sand filtration would make it feasible to use mine water for the cities water supply. This system will be the first of its kind known to produce potable water for a city.

In addition, it is the desire of the city to develop an integrated system that will incorporate the wetlands into an aesthetic, educational, and recreational facility that can be enjoyed by the local populace and will enhance local wildlife habitat.

The model for the constructed wetlands (Fig. 2) was devised as a composite of engineering technology obtained from the Environmental Protection Agency [16] as well as from research conducted by Campbell [17]. An anoxic lime- 
Table 2. Selected Cases Documenting the Amelioration of Mine Drainage by Constructed Wetlands. [AMD, acid mine drainage; Yes indicates that drainage is from mines and has a low pH; Al, aluminum; An, antimony; Ar, arsenic; Ba, barium; Cd, cadmium; Co, cobalt; $\mathrm{Cu}$, copper; Fe, iron; Mn, manganese; N, nickel; $\mathrm{Pb}$, lead; $\mathrm{Zn}$, zinc]

\begin{tabular}{|c|c|c|c|c|}
\hline Area & $\begin{array}{l}\text { General } \\
\text { Location }\end{array}$ & AMD & Contaminants Removed & Reference \\
\hline $\begin{array}{c}\text { Champagne } \\
\text { Creek }\end{array}$ & Butte, MT & YES & $\mathrm{Al}, \mathrm{Fe}, \mathrm{Cd}, \mathrm{Zn}, \mathrm{pH}$ increase & Moore and Kotansky, 2002 \\
\hline Gowan Run & $\begin{array}{l}\text { Near Tulsa, } \\
\text { Oklahoma }\end{array}$ & YES & $\mathrm{Ba}, \mathrm{Cd}, \mathrm{Cu}, \mathrm{Ni}, \mathrm{Zn}$, and $\mathrm{pH}$ increase. & $\begin{array}{c}\text { http://www.epa. } \\
\text { gov/owow/nps/ } \\
\text { Section319III/OK.htm }\end{array}$ \\
\hline Lehang City & Peoples Republic of China & YES & $\mathrm{Mn}, \mathrm{Zn}, \mathrm{Cu}, \mathrm{Pb}, \mathrm{Cd}$, sulfates. & Shu, 1997 \\
\hline $\begin{array}{l}\text { North Pennine } \\
\text { Orefield }\end{array}$ & United Kingdom & YES & $\mathrm{Ar}, \mathrm{Pb}, \mathrm{Cd}, \mathrm{Zn}$ & Nuttall \& Younger, 2000 \\
\hline Outukumpu Zinc & Dublin, Ireland & YES & $\mathrm{Fe}, \mathrm{Zn}, \mathrm{Pb}$, Sulfates & Sullivan, et al. 2000 \\
\hline Springdale & Pennsylvania & YES & $\mathrm{Fe}, \mathrm{Mn}, \mathrm{Co}, \mathrm{Ni}$ & Ye et al., 2001 \\
\hline Unknown & Pennsylvnia & YES & $\mathrm{Al}, \mathrm{Fe}, \mathrm{Mn}$ & Rose et al., 2003 \\
\hline Unknown & Kentucky & YES & $\mathrm{Al}, \mathrm{Mn}$, Sulfate & Barton et al., 1999 \\
\hline Various Mines & Pennsylvania & YES & Sulfate, $\mathrm{Fe}$ & Wieder, 1988 \\
\hline Widows Creek & Tennessee Valley & YES & $\mathrm{Ar}, \mathrm{Pb}$ & Whiting et al., 1999 \\
\hline
\end{tabular}

stone drain (ALD) as well as a reducing and alkalinity producing system (RAP) were included together in order to insure maximum reduction of iron and sulfur as well as reducing the acidity of the water [5].

Phytoremediation tools for the wetland were determined by accessing the Aquatic Plant Information System [18], and by consulting a local ecologist [15], and by assessing local availability.

Gravity will be the driving force for water flow within the wetland. Flow rates and patterns as well as climatic factor adjustments were modeled using the ECO LAB Mike 21 PP HD + MFLOOD COUPLER TM obtained from Danish Hydraulic Institute (DHI). Discharge rates from the mine are determined by city water usage. The proposed 4.86 hectare wetland is designed to accommodate the extraction of $2.27 \times 10^{6} \mathrm{~L}$ of additional water needed by the city while exceeding the minimum required residence time of 12 days [7]. Residence time at each stage of the constructed wetland is controlled by a series of holding pools and plug pipe drains. Water will be transported through the constructed wetland by natural gravitational flow.

Site selection was determined in collaboration with the Sebastian County Soil Conservation district, the Greenwood Park Department, and the local water board. Factors involved in site selection included local geology, hydrology, meteorology, soils, percolation tests, land availability, proximity to current parks and to the current water treatment plant, and cost constraints.
A total of thirty-one water-quality analyses have been conducted at the Greenwood site. These water analyses, the geological reconnaissance, the USGS Coal Quality Database [19] for Greenwood mines, mine maps in a Geographical Information System (GIS) database, and historical waterquality analyses from these sites were studied to evaluate the degree to which they are concentrated in the mine waters, to determine the origin of the constituents, and to devise a constructed wetland which would lower the concentrations of unwanted constituents to a level treatable by current waterplant technology.

\section{WETLAND DESIGN AND CONSTRUCTION}

Greenwood is located in Sebastian County in western Arkansas adjacent to the State of Oklahoma. The northern boundary of Sebastian County is formed by the Arkansas River. The area south of the Arkansas River flood-plain consists of broken hills separated by creeks and small rivers. Using the above stated criteria, a wetland construction site parallel and adjacent to Vache Grasse Creek, a stream located just east of Greenwood (Fig. 1), was selected. The site is ideally situated near the water extraction point. The property is available at low cost, has ideal soil type and hydraulic character, and is accessible from the city's current green space. No residential housing or businesses are located in close proximity to the property, which lessens concern about odors, mosquitoes, and other undesirable side effects that might result from wetland construction. Geologically, the site is located on alluvial soils that cover extensive underlying layers of shale and sandstone that are a part of the Hart- 


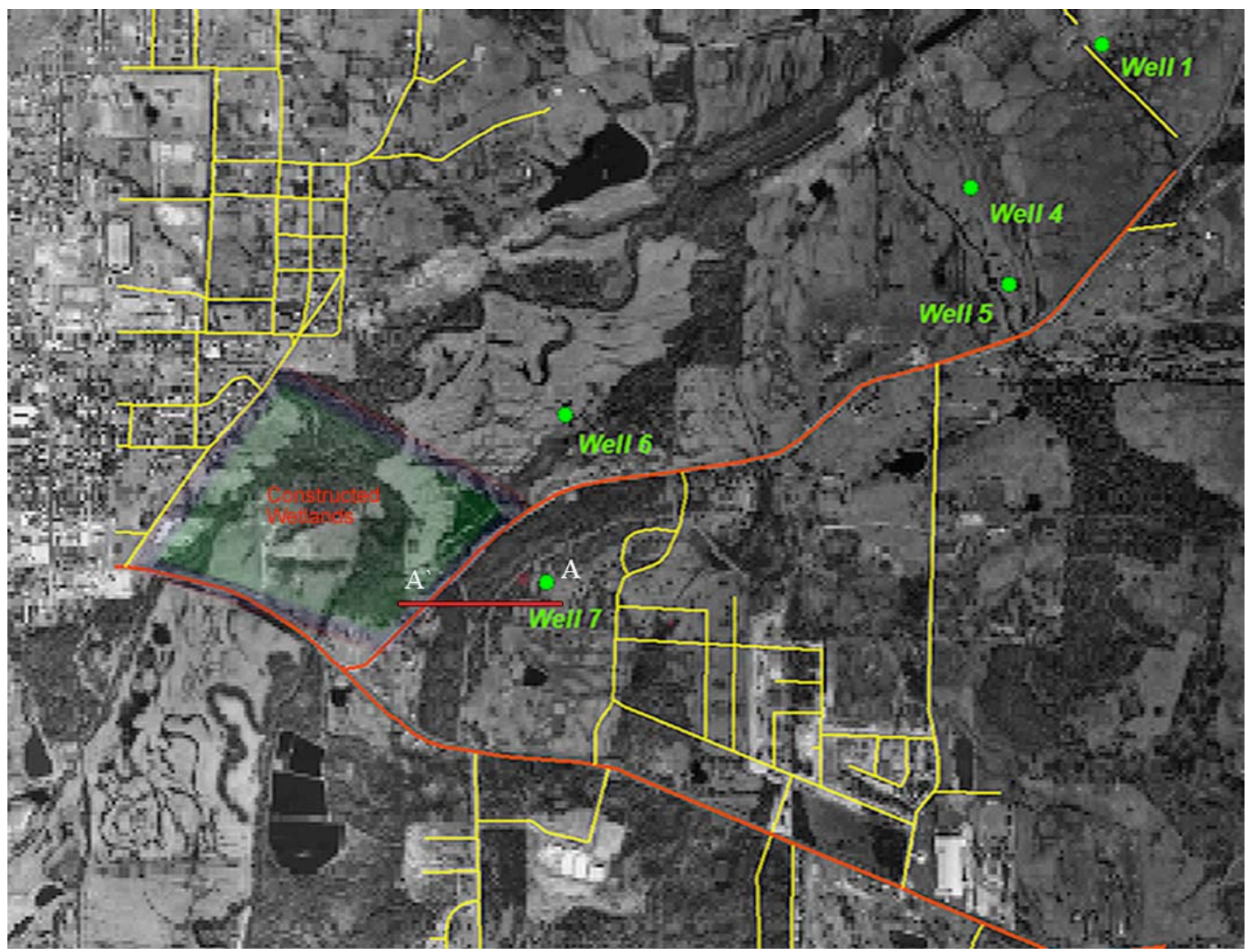

Fig. (1). Wetlands site, Greenwood, AR., 2007.

shorne Formation. These alternating layers of Pennsylvanian sedimentary rock vary in thickness from a few meters on the western up-thrust portion of the formation to depths of nearly $185 \mathrm{~m}$ at the water extraction point. The extensive Atoka sandstone formation is located beneath the Hartshorne [20].

The alluvial soil found at the site is a part of the Taft soil series. These soils are described as poorly drained, level soil on old stream terraces. They are formed from loamy alluvium washed from upland sandstone and shale and are generally have low permeability. The constructed wetlands site has been primarily used for pastureland in the past and is described as having low runoff with a high potential for water retention [20].

Water will be pumped from a $25.4 \mathrm{~cm}$ diameter well drilled into the main mine shaft of the Greenwood \#2 mine. The void space at the extraction point is from 1.2-1.8 m thick and lies $180 \mathrm{~m}$ beneath the surface. A submersible electric pump will extract a maximum of $2.27 \times 10^{6} \mathrm{~L} / \mathrm{d}(30 \mathrm{~L} / \mathrm{s})$ of water from the site and transport it by gravitational flow through a $25.4 \mathrm{~cm}$ pipe to the wetlands which lie at a point $431 \mathrm{~m}$ east and $18.3 \mathrm{~m}$ down-slope from the extraction point (Fig. 1, A-A').

The constructed wetlands system will consist of twelve acres (4.86 hectare) and will contain several distinct units, some of which will be divided into multiple cells (Fig. 2).
The first unit will consist of a holding, aeration, and oxidation pool. Water will exit the $25.4 \mathrm{~cm}$ pipe and be diverted into a lateral distribution pipe $67.3 \mathrm{~m}$ in width which has multiple outlets that will insure uniform influent distribution into the aeration pool. The water will tumble over a triplelevel limestone weir into the holding pool. The $4,529 \mathrm{~m}^{2}$ pool will have an average depth of $1 \mathrm{~m}$, allowing a total pool capacity of $4.53 \times 10^{6}$ L. Retention time for the pool will exceed 15 hours in order to allow complete oxidation of the mine water [3].

As the mine water is oxidized, significant chemical changes will occur within the water as shown below.

$$
4 \mathrm{Fe}^{2+}+\mathrm{O}_{2}+4 \mathrm{H}^{+} \rightarrow 4 \mathrm{Fe}^{3+}+2 \mathrm{H}_{2} \mathrm{O}
$$

The iron III ions then hydrolyze to form iron III hydroxide. Hydrolysis of the ferric ion produces ferric hydroxide, $\mathrm{Fe}(\mathrm{OH})$, and releases additional $\mathrm{H}+$ (acidity). A yellowishorange precipitate known as "yellow boy" forms in the water [8].

$$
4 \mathrm{Fe}^{3+}+12 \mathrm{H}_{2} \mathrm{O} \rightarrow 4 \mathrm{Fe}(\mathrm{OH})_{3}+12 \mathrm{H}^{+}
$$

As the hydrogen ions are exchanged for metals during wetland treatment, solution $\mathrm{pH}$ tends to decrease. Some wetland systems recorded influent $\mathrm{pH}$ near 6.0 and effluent $\mathrm{pH}$ of less than 3.0 [6]. In order to maintain the $\mathrm{pH}$ at a circumneutral range, it is necessary to neutralize acid produced by iron hydrolysis. 
Oxidation pool: Water that has been underground in the coal mine would mix with oxygen in the air. This would turn much of the iron in the water to iron hydroxide, causing it to settle out to the bottom of the pool as a reddish sediment. The plan

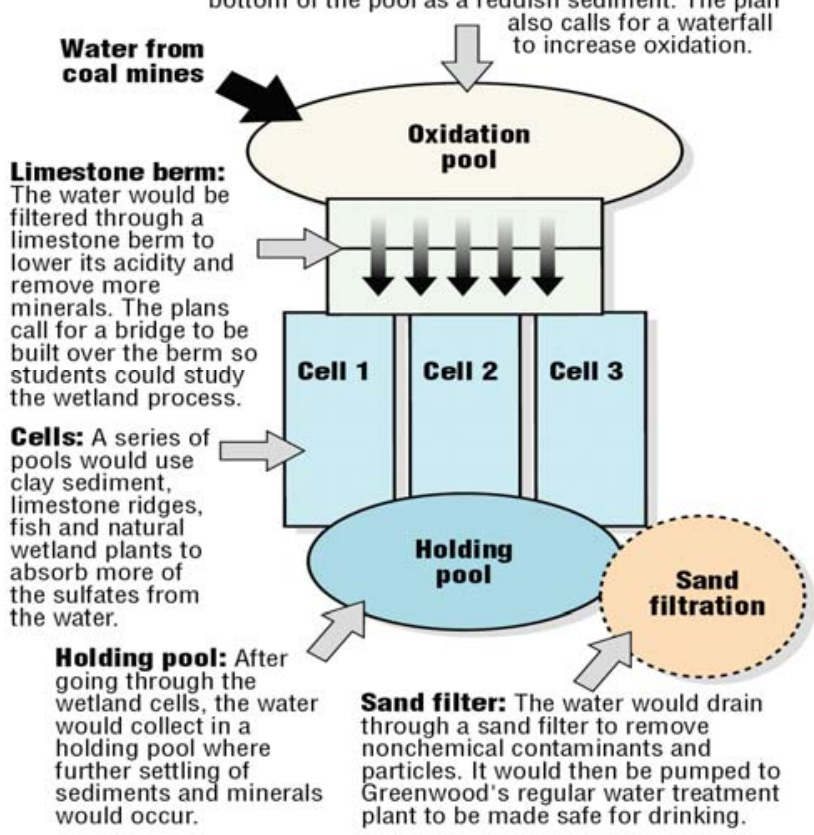

Fig. (2). Conceptual model of the constructed wetlands, Greenwood, Arkansas.

Various approaches have been developed that allow for this neutralization process. One of the most successful is the anoxic limestone drain developed by the TVA. This type of drain consists of a trench back-filled with gravel-sized, crushed, high calcium-carbonate limestone. The limestone is capped with plastic to preclude oxygen infiltration and $\mathrm{CO}_{2}$ exsolution. A protective clay soil is then placed over the fabric. Water is allowed to flow through the limestone, releasing the neutralizing $\mathrm{CaCO}_{3}$,

$$
\mathrm{CaCO}_{3}+\mathrm{H}^{+} \rightarrow \mathrm{Ca}_{2}^{+}+\mathrm{HCO}_{3}^{-}
$$

Neutralization is then accomplished as the bicarbonate reacts with excess hydrogen ions to form water and carbon dioxide,

$$
\mathrm{HCO}_{3}^{-}+\mathrm{H}^{+} \rightarrow \mathrm{H}_{2} \mathrm{O}+\mathrm{CO}_{2}
$$

The containment caused by the burial of limestone within the berm traps $\mathrm{CO}_{2}$ within the treatment system, allowing the development of high $\mathrm{CO}_{2}$ partial pressures, resulting in additional limestone dissolution [21].

Conflicting data exist concerning the effectiveness of using the standard anoxic limestone drain (ALD) system. Limestone within the ALD can be armored by iron hydroxide dropping out of the system which will lead to eventual clogging of the system. Watzlaf [3], indicate that this process occurs very rapidly and leads to rapid failure of the system. In contrast, Brodie [6], estimates the life span of the typical ALD used by the TVA as exceeding 30 years. In order to preclude clogging of the limestone drain by the armoring effect of the iron hydroxides, a decision was made to construct the ALD system (Fig. 3) but to also include a multilayered geotextile on the upgradient side of the berm. The geotextile will consist of a very fine $(2 \mathrm{~mm})$ mesh plastic that will mechanically strain any hydroxide strands that enter the ALD. When the outer-textile becomes clogged, the layer can be easily removed along with the enmeshed iron hydroxide. This is an innovative and inexpensive approach that was tested on site and proved quite successful [14].

The aeration and oxidation pool should allow water to precipitate iron hydroxides. The $\mathrm{pH}$ of the resultant water will lessen as it resides in the pool. The ALD will release bicarbonate ions which will begin the neutralization process. Water exiting the ALD will drain into three parallel, narrow, long pools $(20.6 \mathrm{~m}$ by $63.7 \mathrm{~m})$. Water depth within the pools will exceed $2 \mathrm{~m}$ and will yield an amount $>7.6 \times 10^{6} \mathrm{~L}$. This will allow sufficient head pressure to move the water through the substrate [5].

The reducing and alkalinity-producing systems (RAPS) are designed both to reduce acidity and to promote microbial action [3]. These systems contain a substrate of limestone 1 $\mathrm{m}$ thick. The limestone contains a network of perforated pipes which are connected to a central drain into the adjacent wetlands. A layer of organic material (composted mushroom waste) $1 \mathrm{~m}$ thick is placed over the limestone.

Alkalinity within the RAPS is produced both by limestone dissolution and by sulfate reduction. When mine water flows through an anaerobic environment that contains an organic substrate, the water chemistry can be affected by bacterial sulfate reduction. The bacteria oxidize the organic compounds using sulfate as the electron acceptor and release hydrogen sulfide and bicarbonate [3],

$$
2 \mathrm{CH}_{2} \mathrm{O}+\mathrm{SO}_{4}{ }^{2-} \rightarrow \mathrm{H}_{2} \mathrm{~S}+2 \mathrm{HCO}_{3}{ }^{-}
$$

Conditions within the RAPS system promote the microbial action by providing the low-molecular weight compounds that the bacteria use. These sulfate reducing bacteria are very active when the $\mathrm{pH}$ is $>5$ but can be active at a lower $\mathrm{pH}$ due to the presence of near-neutral $\mathrm{pH}$ microenvironments. Once the microenvironments become established, they generate more alkalinity and these microenvironments become larger and more active.

Field tests show that relatively high rates of limestone dissolution occur within the initial 15 hours of contact with the limestone [5], and lessen afterward so ideal residence time for the RAPS is 15 hours. During this time, the water filters through the organic substrate and is subjected to various and diverse physical, mechanical, and chemical changes. Iron compounds precipitate in the organic substrate as iron hydroxide and other iron compounds. Microbial actions occurring within the anaerobic waters of the substrate allow for the reduction of sulfate ions. The sulfur can be released as $\mathrm{H}_{2} \mathrm{~S}$ or combine with various metals which are precipitated as metal sulfides. The first metal sulfide to form is $\mathrm{CuS}$ followed by $\mathrm{PbS}, \mathrm{ZnS}$, and $\mathrm{CdS}$. FeS can precipitate, removing more iron from the water. $\mathrm{MnS}$ is more soluble and rarely is precipitated in RAPS. Contaminant removal rates for five passive treatment systems averaged $10 \mathrm{~g} \mathrm{~d} / \mathrm{m}^{2}$ for iron and $0.5 \mathrm{~g} \mathrm{~d} / \mathrm{m}^{2}$ for manganese [3]. Achieving this rate will eliminate these contaminants from the Greenwood mine water. Sulfate levels within the mine water exceed $800 \mathrm{mg} / \mathrm{l}$. Total removal of the sulfate within the $2,271 \mathrm{~m}^{3}$ water used from the mine would require the removal of $148.2 \mathrm{~kg} / \mathrm{d}$ sulfur. Under optimum field conditions, only about 0.3 mole $(2.9 \mathrm{~g})$ 


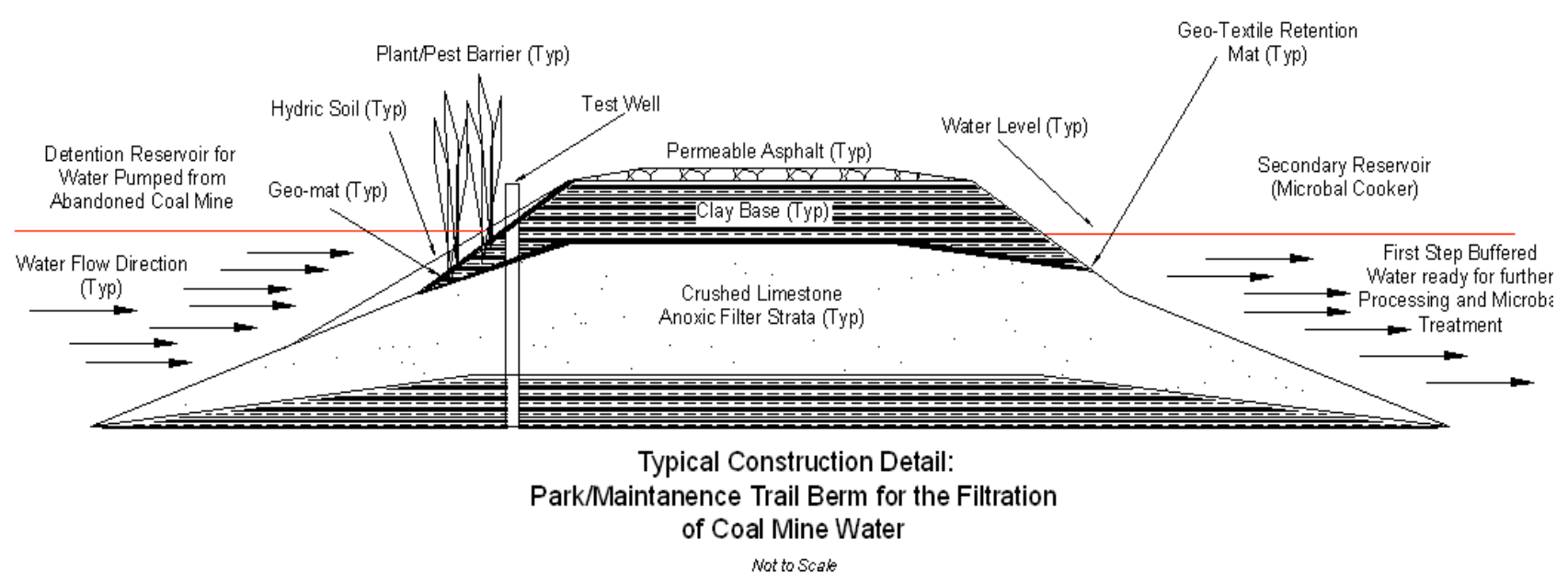

Fig. (3). Berm construction for an ALD. A layered, porous geotextile will be placed over the limestone on the upslope side of the berm (T. Mcguire, 04).

sulfur per day $/ \mathrm{m}^{3}$ is removed [5]. The Greenwood RAPS measuring 0.40 hectare and having a $2 \mathrm{~m}$ substrate should reduce sulfate within the water by $18 \%$. The system should release $30-60 \mathrm{~g} / \mathrm{d} / \mathrm{m}^{3}$ of neutralizing bicarbonate ion which will raise the $\mathrm{pH}$ back to circumneutral levels.

Water will exit the RAPS into a 0.2 hectare holding pool. The pool will exceed $1.8 \mathrm{~m}$ in depth and hold $>1.9 \times 10^{6} \mathrm{~L}$ of water. Plug type pipe systems will allow the water to exit into a traditional free-water surface (FWS) wetland [22]. The drain systems will also allow for the installation of pumps that can be used to backwash the RAPS system if needed.

The 3.24 hectare wetlands are aesthetically designed to blend into the landscape and to allow for the development of hiking and exercise trails. The wetlands will consist of three cells which are $254 \mathrm{~m}$ long and $43.4 \mathrm{~m}$ wide. The low porosity of the alluvial Taft soils allows for the construction of the shallow wetlands without the use of liners. Water depth will average $0.5 \mathrm{~m}$ but will vary from a few $\mathrm{cm}$ to $>1 \mathrm{~m}$ in some of the deeper pools. The removed topsoil will be used to reline the constructed wetland and will provide the base for plant growth. Hay bales will slow and divert the water flow through the wetlands and will also provide organic mass for microbial growth to increase the decomposition of sulfate.

Very low gradient (slope of $<1 \%$ ) will allow the water to move to the 0.4 hectare $\left(>8.0 \times 10^{6} \mathrm{~L}\right.$ water) collection pool, through the rapid sand filter ( $1 \mathrm{~m}$ sand) where it will be extracted and piped to the current water treatment facility.

Residence time for the water in the system was determined by using the following formula [7]:

$$
\mathrm{t}=\frac{(\mathrm{LW} \mathrm{dn})}{\frac{\mathrm{Q}_{1}+\mathrm{Q}_{2}}{2}}
$$

where $\mathrm{t}=$ time

$$
\begin{aligned}
& \mathrm{L}=\text { length } \\
& \mathrm{W}=\text { Width } \\
& \mathrm{n}=\text { porosity (volume not occupied by the plant material) } \\
& \mathrm{d}=\text { depth of flow }
\end{aligned}
$$

$$
\begin{aligned}
& \mathrm{Q}_{1}=\text { influent flow (gpd) } \\
& \mathrm{Q}_{2}=\text { effluent flow (gpd) }
\end{aligned}
$$

Total residence time for Greenwood wetland exceeds 17 days including a 7-day residence time within the wetlands. This exceeds Moshiri's [7] recommendations of 12 total days within the system with a 3.5 day minimal residence time in wetlands.

Precipitation rates in Greenwood average $1.22 \mathrm{~m}$ per year. Rainfall amounts vary seasonally with a high of 14.7 $\mathrm{cm}$ in May and $13.2 \mathrm{~cm}$ in November. Rainfall amounts have been known to exceed $10.2 \mathrm{~cm}$ during a 24 hour period, a situation which can cause local flooding, especially in the wetland area. Berm construction should prevent flooding within the wetland area. The pumping rate can be adjusted at the well-head to account for both rainfall and evapotransporation rates that occur in Greenwood and to maintain a constant flow and uniform residence time within the wetlands.

Vegetation plays an important role within the wetland, both for the remediation of acid mine drainage and for its influence on other wetland characteristics. Perennial vegetation can be established by the placement of rhizomes or transplanted plants directly into the soil substrate. It is generally best to use plants that are native to the area. Typha latifola (cattail) have proven to be one of the most adaptive and effective plants found in wetlands, and local stocks are available. Typha latifola are acid tolerant and thrive under a variety of environmental conditions. They also have the ability to adsorb iron and manganese [23], dropping manganese levels from $>30 \mathrm{mg} / \mathrm{L}$ to $2 \mathrm{mg} / \mathrm{L}$ in one wetland. In the Smith [23], study, iron concentrations dropped from $25 \mathrm{mg} / \mathrm{l}$ to 1 $\mathrm{mg} / \mathrm{L}$.

Common reed (Phragmites) is one of the more widely used plants in constructed wetlands and has excellent growth characteristics in shallow water. Duckweed (Lemna) is also commonly used and multiplies rapidly to form a surface seal which lessens aeration and evaporation. It grows well with various macrophytes, including the two previously mentioned. Various other wetland biota can be added, including the common bulrush (Scirpus validus), but a combination of 
the above generally proves most successful in the southern United States. Additional aquatic plants including Iris ssp., southern wild rice (Aizanias miliacea), flowering rush (Butomus umbellatus), marsh marigold (Caltha palustris), arum lily (Zantedeschia aetiopica), and various ferns, cane, or bamboo can be added for aesthetics [24].

Plants have the ability to remove not only iron and manganese, but other metals and contaminants as well. Metals may be incorporated into the biomass as the plant grows. Macrophytes take up metals through the root system and distribute them throughout the plant [4]. The extent of uptake is dependant upon the type of plant and the metal that is being removed. Plant roots can remove arsenic and other heavy metals [25]. Duckweed has been shown to be an excellent accumulator of cadmium, copper, and selenium.

Exchanges between dissolved metals and humic acids in the substrate of the wetlands can cause additional and significant reduction in metal concentrations. The wetland sediments are generally anaerobic below the surface and contain organic carbon for microbial growth. Several chemical and biological processes combine to remove metals and contaminants from the water entering the wetlands. Removal mechanisms include cation exchange, chelation with wetland soils, binding with humic materials, precipitation as insoluble salts of sulfides, carbonates, and hydroxides, as well as uptake by plants, algae, and bacteria [4].

Greenwood is concerned about possibilities of organic compounds entering the water from abandoned landfills. Wetlands have demonstrated the ability to separate and to transform these materials through volatilization, sedimentation, biodegradation, sorption, and uptake [4]. Although the rates are variable, water monitoring should indicate the proficiency of the wetlands in removing these contaminants.

Sulfate reduction will be of primary concern within the wetlands. Watzlaf [5], measured sulfate reduction in RAPS at $0.3 \mathrm{~mol} / \mathrm{d} / \mathrm{m}^{3}$. Using the Watzlaf calculation, the system in Greenwood has the capacity to lower the levels by $18 \%$ to $723 \mathrm{mg} / \mathrm{L}$. Because the sulfate in the RAPS is several orders of magnitude greater than the metals, it would not be possible to remove the sulfate completely using only the RAPS.

Additional and significant sulfate reduction should occur within the wetlands. Excess calcium produced from limestone dissolution within the AMD and RAPS system should result in precipitation of calcium sulfate (gypsum) in the tailwaters entering the wetlands.

Sulfate reduction in two AMD sites in Ohio [24] showed sulfate removal by bacteria (in wetlands) to vary from $45 \%$ in winter to $55 \%$ during the summer months. Natural wetlands in Yugoslavia demonstrated sulfate losses ranging from 45-67\% [25]. Adding bales of hay and other organic matter such as peat, wood shavings, or compost to the wetlands and holding pool will result in greater sulfate reduction. The low-molecular weight compounds that sulfate reducing bacteria utilize are common in the microbial fermentation processes in anoxic environments [5]. These bacteria, such as those in the genera Desulfovibrio and Delsulfotomaculuum, employ sulfate in the anaerobic respiration process, resulting in net sulfate decreases [23]. Additional organic matter will also accumulate in the wetlands as biota become established and add detritus to the substrate. As the microbes become established in this matter, they generate increasing amounts of alkalinity and the microbes become more numerous, thus creating additional reductions in sulfate.

The goal to reduce sulfate levels to a maximum of 250 $\mathrm{ml} / \mathrm{L}$ after sand filtration is expected to be achievable but will require frequent monitoring. If sulfate levels exceed the expected amount, dilution within the city reservoir will lower sulfate concentrations to acceptable levels prior to treatment.

Water exiting the wetlands will be contained in a collection pool 0.4 hectare in size. Water depth in the pool will exceed $1.8 \mathrm{~m}$, allowing for the collection of $>3.8 \times 10^{6} \mathrm{~L}$ of water. Water will pass through a screening device and enter a $9.3 \mathrm{~m}^{2}$ filtration area. The substrate of this filtration pool will consist of $1.5 \mathrm{~m}$ gravel and large grain sand. Withdrawal pipes will be embedded in the substrate. Water will filter through the substrate and enter a branching spider pipe system. The spider pipe system will drain into a $25.4 \mathrm{~cm}$ drain pipe and then be pumped to the city treatment plant for chlorination and further treatment. Expected discharge rate for the system is $2.3 \times 10^{6} \mathrm{~L} / \mathrm{d}$.

The city wishes to incorporate the wetlands into the present city greenspace and park system. In order to do this and to create a viable park, plans are to buy the entire 25.9 hectare plot (Fig. 1). The water from the wetlands will exit at Vache Grasse Creek near the city municipal building and adjacent to the current museum and coal miner's memorial. A wooden bridge crossing the creek will connect the two systems. A walking/bike trail and exercise path of asphalt will be constructed on the berms throughout the wetland and adjacent park area. Asphalt paths will also provide access to the low-land hardwood forest and meadow found at the site. Interpretive signs will provide educational information on wetland flora and fauna and the ecology of the wetlands. Several wooden foot bridges will be constructed across various portions of the wetlands which will allow visitors to view the unique ecology found in wetlands.

Access to the area around the RAPS system can be obtained by groups from local schools and other educational facilities. Plans exist to develop an outdoor facility which will serve as a meeting area for these groups and also serve as an outdoor classroom. A complete unit of study for K-12 classrooms will be developed that will incorporate wetland ecology, conservation, and hydrology into the curriculum. Student groups can help monitor the park, the wetland, and the water quality within the system. Additional educational roles may include construction and placement of martin houses and other wildlife enhancement activities.

\section{CONCLUSION}

Greenwood, Arkansas experiences water demand in excess of the ability of the city reservoir. The coal mines in Greenwood, Arkansas have an estimated storage of available water in excess of $1.97 \times 10^{9} \mathrm{~L}$. The water has been extensively studied over a three year period. Results have indicated that the water could be utilized for municipal purposes if sulfate, iron, and other undesirable materials can be removed. 
Constructed wetlands have been successfully used worldwide for the treatment of waste and mine water. Additionally, many cities use rapid sand filtration as part of water treatment [24]. These studies indicate the potential for passive remediation of water.

Greenwood, Arkansas can save in excess of twenty million dollars by using the coal mines and constructed wetland as the water source to augment their present supply [13]. Utilizing water from the mines with the constructed wetland appears scientifically and economically feasible. Frequent monitoring of the water quality within both the mines and wetland should be an integral component of municipal water use from this source.

Construction and development of a wetland facility for the city of Greenwood, Arkansas is a viable and economically-feasible method to meet the water needs of the city. The system has the capability of lowering the contaminant levels of the mine water to meet or exceed those of the raw water within the present reservoir. The one of a kind system utilizing a RAP and ALD system in combination with traditional wetland and sand filtration to produce a potable water supply from abandoned coalmine water is a "green" approach to using available, affordable resources to meet community needs. Coupling the wetland with recreational and educational utilization makes the project even more appealing as well as increases funding opportunities.

\section{REFERENCES}

[1] R. Bastian, Constructed Wetlands for Wastewater Treatment and Wildlife Habitat, United States Environmental Protection Agency, EPA832-R-93-005, 1993, p. 174.

[2] P.F. Cooper, European design and operations guidelines for reed bed treatment systems", WRC Report UI 17, presented to the Conference on Constructed Wetlands in Water Pollution Control, Cambridge, U.K, September 1990, p. 27.

[3] G. Watzlaf, K. Schroeder, R. Kleinmann, C. Kairies, and R. Nairn, The Passive Treatment of Coal Mine Drainage, United States Department of Energy, Pittsburg, PA, 2001, p.126.

[4] Environmental Protection Agency. USA, Constructed Wetlands Treatment of Municipal Wastewaters, EPA Manuel, EPA/625-R99/010, 2000, p. 154.

[5] G. Watzlaf, K. Schroeder, and C. Kairies, "Long-term Performance of Alkalinity- Producing Passive Systems for the Treatment of Mine Drainage", Proceedings of the National Meeting of the American Society for Surface Mining and Reclamation: Tampa, FL, 2000, pp. 262-274.

[6] G.A. Brodie, Achieving Compliance with Staged, Aerobic Constructed Wetlands, Annual Meeting of the American Society of Surface Mining Reclamationists, Durango, CO, 1991, p.151.

[7] G. Moshiri, Constructed Wetlands for Water Quality Improvement, Lewis Publishers, Boca Raton, FL, 1993, p. 614.
[8] W. Hobba, Underground Coal Mines as Sources of Water for Public Supply in Northern Upshur County, West Virginia, U.S. Geological Survey, Charleston, West Virginia, 1987.

[9] J. Demchak, L. Mcdonald, and J. Skousen, Water Quality from Underground Coal Mines in Northern West Virginia (1968-2000), Chambers Environmental Group, Inc, and West Virginia University, Morgantown, WV, 2001, p. 22.

[10] D. Cumbie, and J. Dinger, "Abandoned underground coal mines as potential municipal water supplies in the Eastern Kentucky coal field" Kentucky Water Resources Annual Symposium Proceedings, 11 Feb 1998.

[11] R. Manley, LaFlore County Water Data, Oklahoma Department of Environmental Quality, Southeast Region, Wilburton, OK, 2004, p.8.

[12] J. V. Brahana, and C. Varnell, "Factors affecting water quality and surface water/ground water interaction, Greenwood, Arkansas" AWRC Annual Conference, Fayetteville, April 22 /23, 2003.

[13] G. Robb, "Environmental consequences of coal mine closure," Geographic. J., vol. 160, Issue 1, pp. 33-40, 1994.

[14] N. Adams, D. Carroll, K. Madalinski, and S. Rock, Introduction to Phytoremediation, National Risk Management Research Laboratory, United States Environmental Protection Agency, EPA/600/R99/107, 2000, p. 72.

[15] R. Nairn, R. Hedin, and G. Watzlaf, "Generation of alkalinity in an anoxic limestone drain" Achieving land use potential through reclamation, Proc. Conf. of the 9th National American Society for Surface Mining and Reclamation Meeting, Princeton, WV, 1992, pp. 206-219.

[16] T. Wildeman, and E. Bates, Handbook for constructed wetlands receiving acid mine drainage, EPA Superfund Innovative Technology Evaluation, EPA/540/SR-93/523, 1993, p. 93.

[17] C. Campbell, and M. Ogden, Constructed Wetlands in the Sustainable Landscape, John Wiley and Sons, Inc., New York, 1999, p. 271.

[18] U.S. Army Corps of Engineers, "Aquatic plant information system (APIS)", United States Army Corps of Engineers. Available at: http://el.erdc.usace.army.mil/aqua/apis/apishelp.htm [accessed November 6, 2003].

[19] L. Bragg, J. Oman, S. Tewalt, C. Oman, N. Rega, P. Washington and R. Finkelman, "National coal resource data system", U.S. Geological Survey Open-File Report 97-134, 2003, p. 127.

[20] J. Cox, B. Garner, and F. Vodrazka, Soil Survey of Sebastian County, Arkansas, United States Department of Agriculture, March, 1975, p. 63.

[21] U.S. Environmental Protection Agency, "Arsenic Treatment Technologies for soil, waste, and water", EPA-542-R-02-00, 2002, p.73.

[22] R. Wass, Free Water Surface Wetlands for Wastewater Treatment, A technology assessment, United States Environmental Protection Agency, EPA 832-S-99-002, 1999, p. 117.

[23] K. Smith, Constructed Wetlands for Treating Mine Drainage, Restoration and Reclamation Review, University of Minnesota, (Hort 5015/5071), vol. 2, Spring ed., 1997, p. 14.

[24] B. Maynard, and A. Flege, "Sulfur isotopes as a guide to sulfate reduction in wetlands receiving acid mine drainage", Geol. Soc. Am., vol. 34 (4), 2002.

[25] S. Groudev, I. Spasnova, G. Plamen, N. Manina, "Bioremediation of acid drainage in a uranium deposit", 14th Annual West Coast Conference on Soils, Sediments, and Water, Association for Environmental Soils and Health, San Diego, California, March 16, 2004, p. 8. 